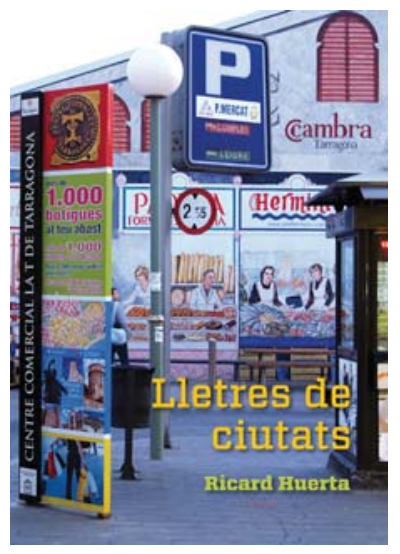

\title{
Lletres de ciutats
}

Ricard Huerta

Edicions de la Universitat de Lleida, 2014

$141 \mathrm{pp}$.

ISBN 978-84-8409-634-4

Ricard Huerta nos propone en este libro un paseo por las letras que constituyen las imágenes y la vida en siete ciudades del mediterráneo peninsular. En forma de un diálogo sugerente con siete personas que las han habitado, este paseo se convierte en un descubrimiento plagado de significaciones. El trabajo, presentado como una entrevista, se enmarca dentro de los estudios culturales, la cultura visual y las historias de vida, situándose en Alicante, Barcelona, Girona, Lleida, Palma, Tarragona y Valencia. No obstante, lo leemos como un libro de viajes, en el que la voz de los siete cicerone excepcionales nos guía a través de las calles y grafías en cada ciudad, en un recorrido, que a ellos mismos sorprende, de la misma manera que sorprende a la lectora, al rememorar las imágenes de ciudades ya conocidas invitándola a volver a visitarlas para redescubrir letras escondidas para el visitante foráneo.

La discusión se combina con los letreros, en una composición en cada caso distinta, en historias de vida, que son también las historias recientes de los guías/cómplices de Ricard Huerta. Los letreros se combinan con narraciones que tienen el encanto de ser singulares y experienciales, y por tanto únicas, aunque probablemente en parte compartidas por las personas de una misma generación en cada ciudad. Se liga la experiencia personal con las tradiciones, o mejor dicho, con las costumbres de los habitantes. Se une el presente con el pasado, proporcionando una nueva mirada de contenido histórico que convierte en patrimonio unas pocas letras que simbolizan, no solo un desarrollo estético, sino también vivencial y político. Las letras de cada una de estas ciudades cobran vida con este acompañamiento; descubrimos Alicante de la mano de Joan Van der Hofstad, alicantino de origen belga y autor de diseños para el MARQ, Barcelona con Pilar Vélez, directora de DissenyHub, Girona con Mariona Masgrau, de ColActiva, Lleida con Gloria Jové, maestra y formadora de maestros de la Universitat de Lleida, Palma conJoanaCotoner, restauradora y anticuaria, Tarragona con Carles Marqués, escritor y guionista, gestor cultural yautor de una guía de Tarragona, y Valencia con Ramón Lapiedra, profesor de astrofísica i ex-rector de la Universitat de València. 
Nos convertimos en viajeros, los guías, el autor y nosotros, que compartimos durante la lectura aquel extrañamiento necesario para modificar nuestra mirada, centrarla, desenfocarla, enriquecerla con olores, colores, personas, movimientos artísticos y también sociales, momentos históricos. Paseamos por ciudades conocidas con una nueva mirada transformadora para todas y todos nosotros, ya que nunca más podremos caminar por sus calles sin prestar atención, sin mirar hacia arriba, como dice una de las interlocutoras.

Esta nueva lectura se convierte en un método, en una posibilidad pedagógica, en una actitud de descubrimiento de un patrimonio cotidiano muchas veces ignorado, que de tanto verlo, ya no miramos.

La lectura de Lletres de ciutats es sencilla, como un libro de viajes, como siete cuentos de ciudades, en el que se integran las letras: letras romanas, modernistas $\mathrm{y}$ art déco, y artistas fundamentales en la creación de este patrimonio material e inmaterial: Baeza, Crous-Vidal, Marés, Mariscal, Joan Brossa...

Convergen el conocimiento cultural y profesional de cada uno, con la mirada a las manifestaciones de la cultura visual y con las trayectorias en las políticas culturales de las ciudades, haciéndonos conscientes de la importancia de tener un criterio estético en la conservación del patrimonio creado y vivido. Conciencia que deriva en la responsabilidad de los creadores de este patrimonioy de los políticos hacia la valorización y protección, y de los educadores y educadoras en el conocimiento, en la educación de las miradas, que lo aproximan y lo hacen propio, para el disfrute de una cultura compartida.

Paula Jardón Giner. Universitat de València 